\title{
Salt Leaching with Brackish Water during Growing Season Improves Cotton Growth and Productivity, Water Use Efficiency and Soil Sustainability in Southern Xinjiang
}

\author{
Chao Xiao ${ }^{1,2,+}$, Meng Li ${ }^{3,4,+}\left(\mathbb{D}\right.$, Junliang Fan ${ }^{1,2, *} \mathbb{C}$, Fucang Zhang ${ }^{1,2, *} \mathbb{C}, \mathrm{Yi} \mathrm{Li}^{1,2}$, Houliang Cheng ${ }^{1}$, Yuepeng Li ${ }^{1}$, \\ Xianghao Hou ${ }^{1}$ and Junqing Chen ${ }^{1}$
}

1 Key Lab of Agricultural Soil and Water Engineering in Arid and Semiarid Areas, Ministry of Education, Northwest A\&F University, Yangling 712100, China; xiaochao@nwafu.edu.com (C.X.); liyi@nwafu.edu.cn (Y.L.); chenghouliang@nwafu.edu.cn (H.C.); liyp@nwafu.edu.cn (Y.L.); houxianghao@nwafu.edu.cn (X.H.); junqingchenn@nwafu.edu.cn (J.C.)

2 College of Water Resources and Architectural Engineering, Northwest A\&F University, Yangling 712100, China

3 State Key Laboratory of Desert and Oasis Ecology, Xinjiang Institute of Ecology and Geography, Chinese Academy of Sciences, Urumqi 830011, China; lm@ms.xjb.ac.cn

4 Akesu National Station of Observation and Research for Oasis Agro-Ecosystem, Akesu 843017, China

* Correspondence: nwwfj1@163.com (J.F.); zhangfc@nwsuaf.edu.cn (F.Z.)

+ Authors contributed equally to this work.

check for updates

Citation: Xiao, C.; Li, M.; Fan, J.; Zhang, F.; Li, Y.; Cheng, H.; Li, Y.; Hou, X.; Chen, J. Salt Leaching with Brackish Water during Growing Season Improves Cotton Growth and Productivity, Water Use Efficiency and Soil Sustainability in Southern Xinjiang. Water 2021, 13, 2602. https://doi.org/10.3390/w13182602

Academic Editor: Antonio Lo Porto

Received: 22 July 2021

Accepted: 16 September 2021

Published: 21 September 2021

Publisher's Note: MDPI stays neutral with regard to jurisdictional claims in published maps and institutional affiliations.

Copyright: (c) 2021 by the authors. Licensee MDPI, Basel, Switzerland. This article is an open access article distributed under the terms and conditions of the Creative Commons Attribution (CC BY) license (https:// creativecommons.org/licenses/by/ $4.0 /)$.

\begin{abstract}
Low water use efficiency and soil salinization are two main factors limiting cotton production in southern Xinjiang. A field experiment was conducted to investigate the effects of brackish water irrigation levels on cotton growth, yield and soil water-salt dynamics in southern Xinjiang, so as to provide a theoretical and experimental basis for the development and utilization of brackish water. There were three irrigation levels: $\mathrm{W}_{1}\left(75 \mathrm{~mm}+80 \% \mathrm{ET}_{\mathrm{c}}\right), \mathrm{W}_{2}\left(150 \mathrm{~mm}+80 \% \mathrm{ET}_{\mathrm{c}}\right)$ and $\mathrm{W}_{3}$ $\left(240 \mathrm{~mm}+80 \% \mathrm{ET}_{\mathrm{c}}\right)$ at the seeding stage $\left(\mathrm{S}_{1}\right)$, seeding stage + budding stage $\left(\mathrm{S}_{2}\right)$ and seeding stage + budding stage + flowering stage $\left(\mathrm{S}_{3}\right)$, with an irrigation amount of $450 \mathrm{~mm}$ during spring as the CK (the local reference level) (10 treatments in total). The salt of the local brackish water used was $3 \mathrm{~g} \cdot \mathrm{L}^{-1}$. Film-mulched drip irrigation experiments were conducted to observe cotton growth, aboveground dry matter, cotton yield, soil water and salt distribution, as well as other indicators. The results showed that the irrigation applications of $S_{3}$ can improve the soil moisture and salt distribution of the root zone. The salt accumulation at the harvest stage of $\mathrm{W}_{3} \mathrm{~S}_{3}$ was reduced by $39.5 \%$ and $2.8 \%$ compared with $\mathrm{W}_{3} \mathrm{~S}_{1}$ and $\mathrm{W}_{3} \mathrm{~S}_{2}$, respectively. More frequent irrigation applications can reduce a soil's total dissolved solids (TDS), avoid exceeding the salt tolerance threshold of $4.8 \mathrm{~g} \mathrm{~kg}^{-1}$ and lead to higher aboveground dry matter and cotton yields. $\mathrm{W}_{3} \mathrm{~S}_{3}$ obtained the highest yield of $5685 \mathrm{~kg} \mathrm{ha}^{-1}$, which was increased by $39.59 \%, 7.85 \%$ and $11.25 \%$ compared with $\mathrm{W}_{3} \mathrm{~S}_{1}, \mathrm{~W}_{3} \mathrm{~S}_{2}$ and $\mathrm{CK}$, respectively. The higher the irrigation amount, the less water use efficiency (WUE), following the order of $S_{3}>S_{2}>$ $\mathrm{S}_{1}>\mathrm{CK}$ at various growth stages. $\mathrm{W}_{3} \mathrm{~S}_{1}$ obtained the lowest WUE of $0.64 \mathrm{~kg} \cdot \mathrm{m}^{-3}$. Comprehensively considering the effects of soil moisture retention and salt suppression, cotton growth, yield and water use efficiency, an irrigation amount of $240 \mathrm{~mm}$ brackish water at three growth stages, with $80 \% \mathrm{ET}_{\mathrm{C}}$ for irrigation, is recommended for the sustainable production of cotton in southern Xinjiang.
\end{abstract}

Keywords: cotton; film-mulched drip irrigation; water and salt dynamics; yield

\section{Introduction}

Xinjiang Province is located in the arid region of northwest China, due to its good light and heat resources which can meet the growth needs of mid-late maturity upland cotton and long-staple cotton [1]. It is located in an equatorial region of extreme drought, with low annual rainfall of less than $50 \mathrm{~mm}$. In addition, in the Korla region of southern Xinjiang, soil salinization is serious and saline soils account for $54.95 \%$ of this area. Drought 
and soil salinization have become two key factors restricting the sustainable development of agriculture in this area [2,3]. In recent years, the drip irrigation technology widely implemented in this area has played an important role in alleviating water shortages and improving the utilization efficiency of irrigation water [4,5]. Mulched drip irrigation technology is an advanced integration of water and fertilizer technology, which can control the water and nutrient status of the root zone precisely and in real time, effectively reduce the evaporation between plants and deep seepage, and minimize nutrient leaching $[6,7]$. However, this raises some new questions. In saline-alkali land, salt tends to accumulate in the cotton root zone due to the lower irrigation quota and higher frequency of drip irrigation [8]. Moreover, the excessive reclamation of saline soil and the expansion of the irrigation area will exacerbate the local water shortage. In order to prevent cotton yield reduction caused by the soil's salinity, local farmers often use large amounts of fresh water to leach soil salts in winter or spring. The amount of water used for leaching reaches $6000-10,000 \mathrm{~m}^{3} \mathrm{ha}^{-1}$, which not only reduces the efficiency of irrigation water, but also leads to the rise of the underground water level and aggravates the secondary soil salinization $[9,10]$, with a potential risk to agricultural sustainability. Due to the rich local brackish water resources, a method to efficiently utilize brackish water resources is of great significance to improve water resource utilization efficiency and ensure efficient cotton production.

The exploitation and utilization of brackish water resources is an important method to alleviate the shortage of fresh water [11]. Quantitatively, the global brackish water supply could reach about $1.39 \times 10^{9} \mathrm{~km}^{3}$, accounting for $1 \%$ of the water on the Earth, which is as much as the supply of freshwater [12]. Brackish water is also widely distributed in the local area, it is easily accessible, and it can reduce the salt concentration of salinized soils so as to meet the water requirement of cotton $[10,13]$. However, unreasonable brackish water irrigation schema and excessive salinity of irrigation water quality contribute to the aggravation of secondary soil salinity, which also leads to the accumulation of salts in farmlands and salt stress to plants $[6,14]$. In recent years, scholars have conducted a large number of studies regarding the effects of brackish irrigation on soil water-salt movement, including drip irrigation zone layout, irrigation water quality, irrigation amount and frequency [15-18]. The results showed that the effect of brackish water on soil salinity was mainly concentrated in the surface soil, which significantly affected cotton growth. Under brackish water irrigation, when the single irrigation amount was too small, it would lead to high salt accumulation in the $0-20 \mathrm{~cm}$ soil layer, and the salt accumulation depth increased with the increase in irrigation amount. Xue at al. reported that using brackish and fresh water together was an important way to reduce soil salinity [19]. For example, Hassanli noticed that there was no significant difference between initial and final salt concentrations in the soil profile under alternate irrigation [20]. In addition, irrigation applications with brackish water also had effects on soil water, salt distribution and crop growth. The effects of salt stress on cotton plants are different at different growth stages, and salt stress at seeding stage will affect the morphology and distribution of root growth. Salt stress will inhibit the production of cotton bolls and promote boll abscission [13]. For example, alternate freshwater irrigation after brackish water irrigation can reduce the damage of salt to crops at the salinity sensitive stages [21,22]. Brackish water irrigation has a more complex effect on the dynamics and spatial distribution of water and salts in cotton fields. Using drip irrigation to leach soil salt during the growing season of cotton to keep the soil salinity of the root zone within a certain range has broad application prospects. However, there is still insufficient research on the effect of water and salt movement and cotton growth caused by brackish water irrigation and leaching in different growth stages of cotton, which restricts its promotion and implementation.

Therefore, this study compares the current reality of cotton field agricultural production in southern Xinjiang with the effects of different brackish water irrigation levels on cotton growth, soil water content (SWC) and soil TDS distribution, and cotton yield and WUE at different growth stages of cotton by mulched drip irrigation. This study may 
contribute to determining suitable soil TDS for the growth of cotton and safe brackish water utilization patterns in northwest China.

\section{Materials and Methods}

\subsection{Experimental Site Condition}

The experiments were conducted in a typical salt-alkali cotton field at Yuli County $\left(40^{\circ} 53^{\prime} 0^{\prime \prime}\right.$ N, $86^{\circ} 56^{\prime} 58^{\prime \prime}$ E), Korla, Xinjiang Province (Figure 1) in 2019 from April to October. The experimental site is a typical continental desert climate, with annual mean precipitation of $135.4 \mathrm{~mm}$, mean annual potential evaporation of $2417 \mathrm{~mm}$ and mean annual average temperature of $10.9{ }^{\circ} \mathrm{C}$. The average annual accumulated temperature is $4218.3^{\circ} \mathrm{C}$, the average relative humidity is $45-50 \%$ and the average sunshine duration is $2941.8 \mathrm{~h}$. The experimental area is full of light and heat, which is very suitable for the growth of cotton. A drainage ditch was used to control the underground water level and the depth of the underground water was $3 \mathrm{~m}$. The total precipitation during the cotton growing season was $12 \mathrm{~mm}$. Soil samples in the $100 \mathrm{~cm}$ soil profile were air-dried, and $2 \mathrm{~mm}$ sieved soil samples were used to measure the sand, silt and clay contents of the soil using the Malvern laser particle size analyzer (Mastersizer 2000, Malvern Instruments Ltd., Malvern, UK). The soil texture was classified as sandy loam, and the contents of clay, silt and sand were $1.03 \%$, $20.45 \%$ and $78.52 \%$, respectively. The average soil bulk density was $1.48 \mathrm{~g} \cdot \mathrm{cm}^{-3}$ and the average salt content was $4.2 \mathrm{~g} \cdot \mathrm{kg}^{-1}$.

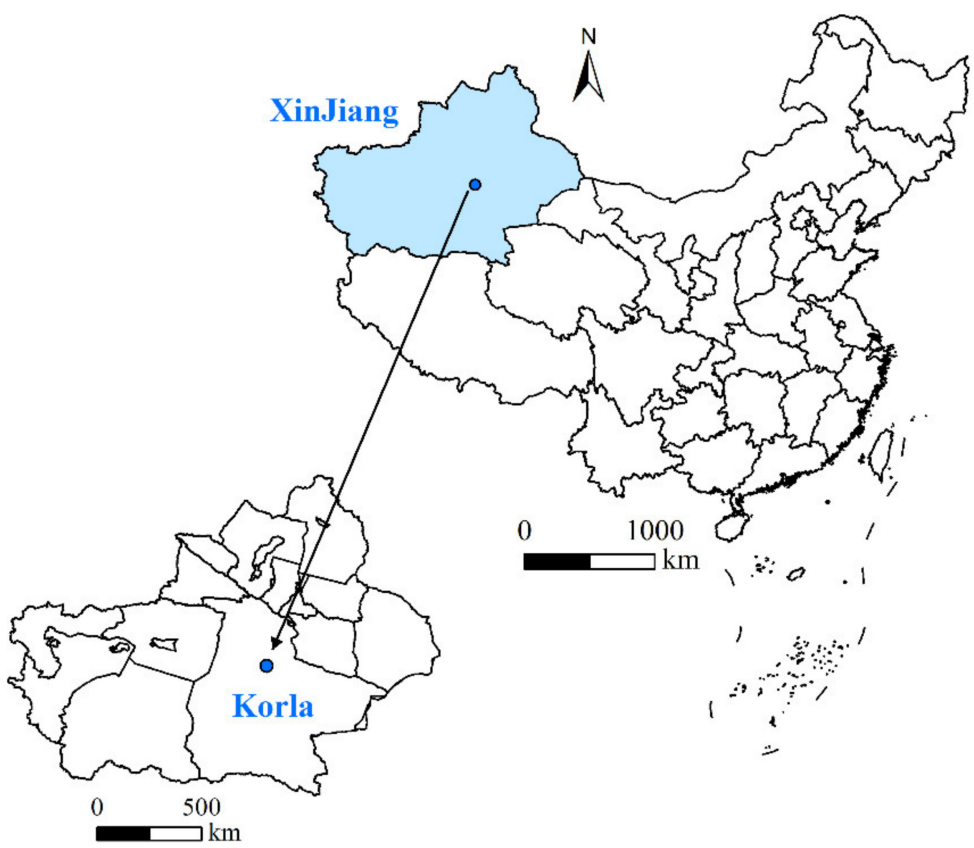

Figure 1. Location of the study area.

\subsection{Experimental Treatments}

The experimental cotton cultivar was "Xinluzhong 67", which was sown on 10 April and harvested on 20 September 2019. The cotton planting mode was one film, two tapes and four rows, which is widely adopted locally. The layout and location of sampling points are shown in Figure 2. The fertilizer rate was based on the local fertilization level: $\mathrm{N}-\mathrm{P}_{2} \mathrm{O}_{5}-\mathrm{K}_{2} \mathrm{O}$ (300-90-45 kg.ha- ${ }^{-1}$ ), and other field management was consistent with the local high yield fields. No winter or spring irrigation was conducted in the experiment field after the cotton harvest in 2018. The cotton was irrigated with $450 \mathrm{~mm}$ of brackish water before sowing, and freshwater irrigation with $80 \% \mathrm{ET}_{\mathrm{c}}$ at the growth stage was used as the CK (the local reference level). Three irrigation levels, $\mathrm{W}_{1}\left(75 \mathrm{~mm}+80 \% \mathrm{ET}_{\mathrm{c}}\right), \mathrm{W}_{2}(150 \mathrm{~mm}+$ $\left.80 \% \mathrm{ET}_{\mathrm{c}}\right)$ and $\mathrm{W}_{3}\left(240 \mathrm{~mm}+80 \% \mathrm{ET}_{\mathrm{c}}\right)$ at the seeding stage $\left(\mathrm{S}_{1}\right)$, seeding stage + budding stage $\left(\mathrm{S}_{2}\right)$ and seeding stage + budding stage + flowering stage $\left(\mathrm{S}_{3}\right)$ were designed as the 
experimental factors following a split-plot design. The ten treatments were conducted with three replicates following the orthogonal test. Each experimental plot was $7 \mathrm{~m}$ long and $5 \mathrm{~m}$ wide. A $2 \mathrm{~m}$ wide protective strip of bare land was set between two plots.

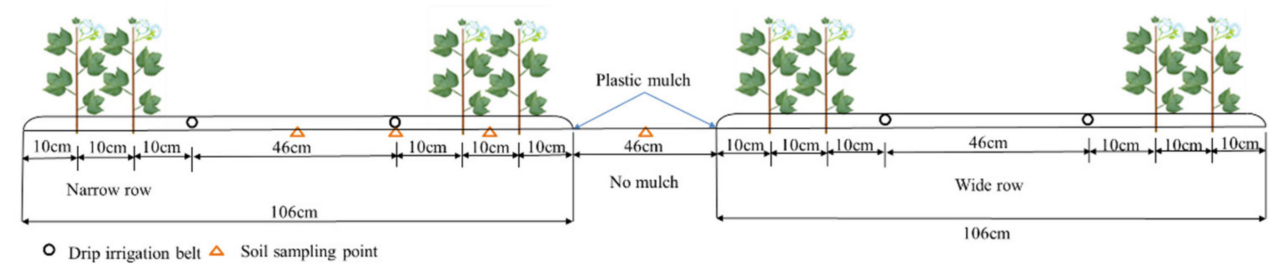

Figure 2. Schematic diagram of experimental planting mode and sampling points.

Actual crop evapotranspiration $\left(\mathrm{ET}_{\mathrm{c}}, \mathrm{mm} \mathrm{d}^{-1}\right)$ was calculated as:

$$
\mathrm{ET}_{\mathrm{c}}=\mathrm{ET}_{0} \times \mathrm{K}_{\mathrm{c}}
$$

where $\mathrm{K}_{\mathrm{c}}$ donates the cotton crop coefficient [23] and $\mathrm{ET}_{0}$ donates the reference crop evapotranspiration calculated with the Penman-Monteith equation [24].

Except for leaching, irrigation began on 27 April and stopped on 20 August with an irrigation interval of 7 days. Irrigation dates were postponed in case of rainfall, and the irrigation amount was $326.3 \mathrm{~mm}$. Spring irrigation (30 March) and irrigation applications at seedling stage (17 April), budding stage (21 June) and flowering stage (27 July) took brackish water with a salinity of $3 \mathrm{~g} \mathrm{~L}^{-1}$, and other irrigation $\left(80 \% \mathrm{ET}_{\mathrm{c}}\right)$ used local channel water with a salinity of $0.7 \mathrm{~g} \mathrm{~L}^{-1}$. In this study, brackish water was used for salt leaching, and fresh water was irrigated 2-3 days after the cotton entered the budding stage and flowering stage, which helped to leach the salt from the root zones.

\subsection{Field Measurements}

\subsubsection{Soil Physical and Chemical Properties}

Soil samples were collected using a soil auger to measure soil water content (SWC) and total dissolved solids (TDS). The measuring depths were 10, 20, 30, 40, 60, 80 and $100 \mathrm{~cm}$. Soil sampling points were set in the middle of wide row, drip line, narrow row and non-mulched areas (Figure 2). The SWC was measured with the drying method [25]. Then, dried soil samples were ground and sieved with a $2 \mathrm{~mm}$ diameter fine screening. Of the sieved soil samples, $5 \mathrm{~g}$ were weighed and put into a conical flask, together with $25 \mathrm{~mL}$ of distilled water. It was then sufficiently shaken to filter all the liquid until it was dry enough to measure TDS. Soil salt accumulation in $0-100 \mathrm{~cm}$ soil was calculated as:

$$
\mathrm{S}=100 \mathrm{CHB}
$$

where $\mathrm{C}$ is the TDS $\left(\mathrm{g} \mathrm{kg}^{-1}\right), \mathrm{H}$ is the soil layer thickness $(\mathrm{cm})$ and $\mathrm{B}$ is the soil bulk density $\left(\mathrm{g} \mathrm{cm}^{-3}\right)$.

\subsubsection{WUE}

WUE was calculated as follows:

$$
\mathrm{WUE}=\frac{\mathrm{Y}}{\mathrm{ET}}
$$

where $\mathrm{Y}$ is the cotton yield $\left(\mathrm{kg} \mathrm{ha}^{-1}\right)$ and ET is the cotton evapotranspiration (mm).

ET was calculated as:

$$
\mathrm{ET}=\mathrm{P}+\mathrm{U}+\mathrm{I}-\mathrm{D}-\mathrm{R}-\Delta \mathrm{W}
$$

where $\mathrm{P}$ is the effective rainfall $(\mathrm{mm}), \mathrm{U}$ is the groundwater recharge, $\mathrm{I}$ is the irrigation, $\mathrm{R}$ is the surface runoff, $\mathrm{D}$ is the deep percolation and $\Delta \mathrm{W}$ is the change in soil moisture 
from the beginning to the end of the experiment. According to the actual situation in the experiments, $\mathrm{U}$ and $\mathrm{R}$ can be ignored.

D was calculated as [26]

$$
\mathrm{D}=\mathrm{M}_{1}+\mathrm{h}-\mathrm{M}
$$

where $\mathrm{M}_{1}$ is the soil moisture before irrigation $(\mathrm{mm})$, $\mathrm{h}$ is the irrigation amount $(\mathrm{mm})$ and $\mathrm{M}$ is the field capacity ( $\mathrm{mm})$.

\subsubsection{Cotton Growth and Yield}

In each plot, four plants were randomly selected to measure plant height, stem diameter, leaf area and aboveground biomass at the seeding stage, budding stage, flowering stage and boll opening stages. Cotton plants were placed in an oven at $105^{\circ} \mathrm{C}$ for $0.5 \mathrm{~h}$ and then weighed at $75^{\circ} \mathrm{C}$ to obtain the dry matter of the aboveground biomass. At harvest stage, three quadrats with the size of $1 \mathrm{~m} \times 1.52 \mathrm{~m}$ were randomly selected for internal yield measurement in each plot. The weight of 100 bolls, the number of plants and the effective boll were measured, and the yield of seed cotton was calculated.

\subsection{Data Analysis}

Excel 2016 and SPSS 23.0 were used to analyze the data. These treatments' means were compared by Duncan's tests at $p=0.05$ significance level [7]. Origin 9.0 and Surfer 9.0 were used to draw the figures.

\section{Results}

\subsection{Effects of Brackish Water Irrigation Amounts and Applications on Dynamic Changes in Soil} Water Content

Figure 3 shows the distributions of SWC in the $0-40 \mathrm{~cm}$ soil layer of each treatment. At the seeding stage, due to the large irrigation amount of $S_{1}$ treatments, the SWC in the whole soil layer was close to the field's capacity, and the difference in SWC was small over depth. The SWC showed a great difference in the horizontal direction (Figure 3a). The SWC in the film-mulched area was significantly higher than that in the non-mulched area. With the increase in the irrigation amount, the SWC in the film-mulched area increased rapidly to the field's capacity. The average SWC of $S_{1}$ was significantly higher than that of the $S_{2}$ and $S_{3}$ treatments (Figure $3 b, c$ ) and increased with the increase in irrigation amount. This may be explained by the horizontal movement of the soil-wetted body.

At the budding stage, the SWC of each treatment increased with the increase in soil depth, and the increase in surface soil was more significant. Besides, for the topsoil in the horizontal direction, the $S_{1}$ treatments (Figure 3a) did not leach salts at this stage, and the SWC in the narrow row decreased gradually due to the plants' water uptake. In addition, the SWC of $S_{1}$ and $S_{2}$ treatments (Figure $3 b$ ) in non-mulched areas was higher than that of $\mathrm{S}_{3}$ treatments (Figure 3c). This was caused by the difference in the single irrigation amount. The higher the single irrigation amount, the more widespread the wetting area.

At the flowering stage, the water consumption of cotton was severe, and the water content in the film of treatment $S_{1}$ and $S_{2}$ was low without irrigation at the flowering and boll stage. In addition, the SWC in non-mulched areas decreased under evaporation. Although CK treatment included no irrigation application, non-mulched areas still maintained a high SWC level (Figure 3d).

At the boll-opening stage, the SWC continued to decrease (Figure 3a,b). However, the SWC in CK treatment did not decrease significantly, which may be due to the high salinity limiting the water absorption of cotton (Figure 3d). The SWC of other treatments remained steady in the horizontal direction because cotton grew slowly and the water supply was terminated. Generally, at the flowering and boll stage, multiple irrigation applications during the growth stages can significantly increase the SWC at $0-40 \mathrm{~cm}$ depth in the film-mulched zones which was more suitable for the water requirements of cotton. Moreover, due to the small amount of single irrigation and the low water content of the 
non-mulched area, it was not easy to produce ineffective evaporation. However, too small of an irrigation amount was also not conducive to an increase of SWC in a narrow row.

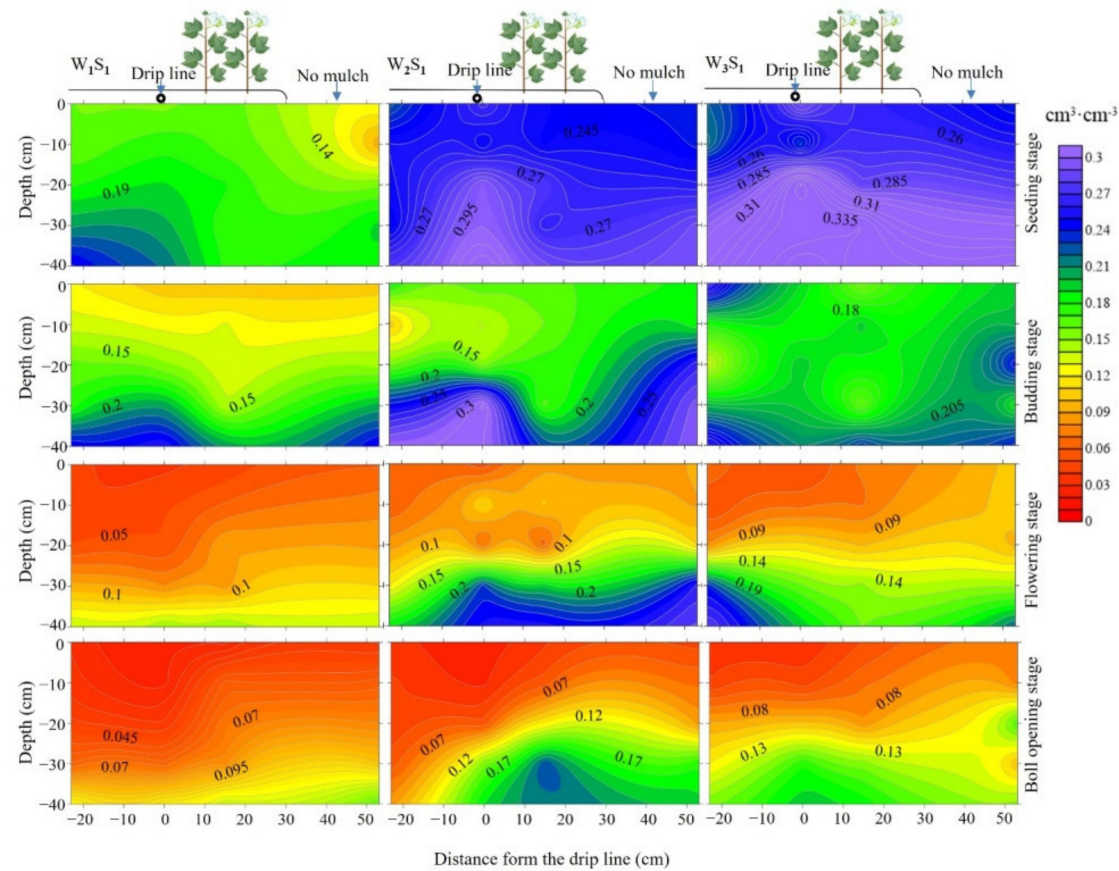

(a)

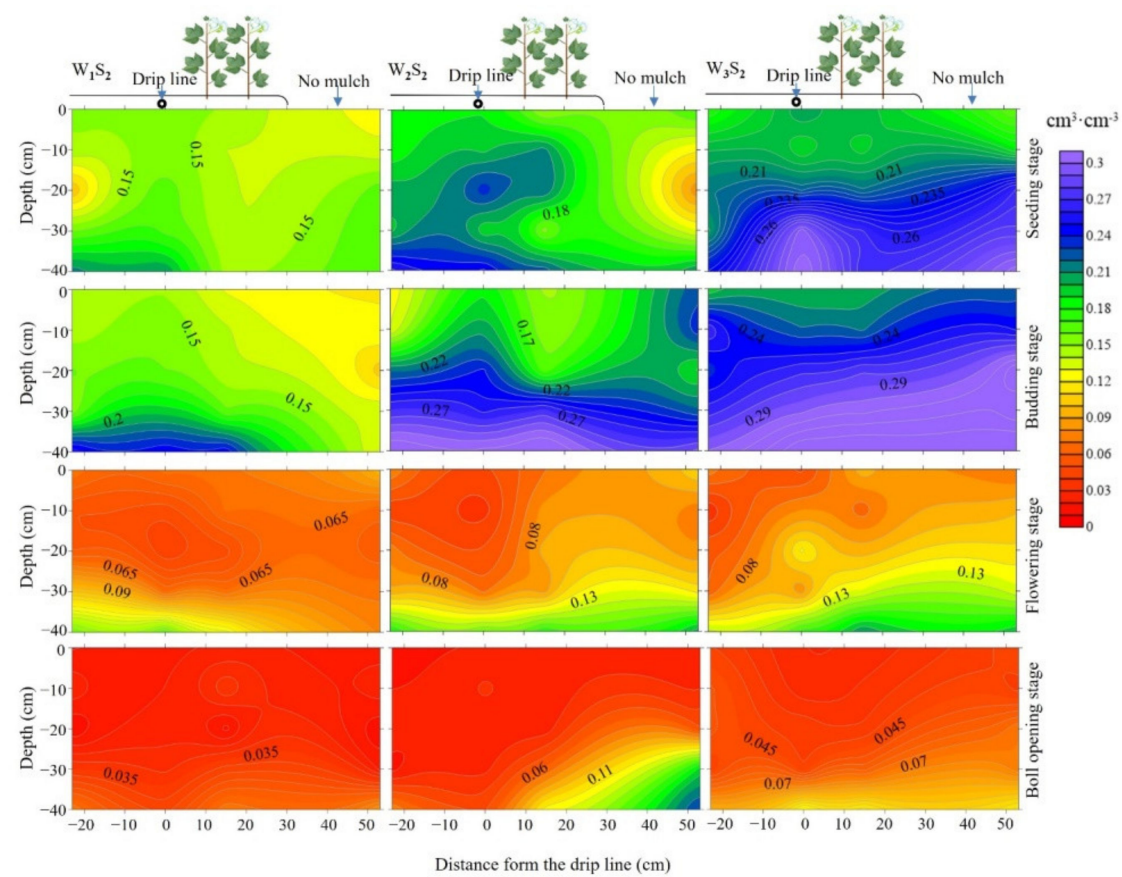

(b)

Figure 3. Cont. 


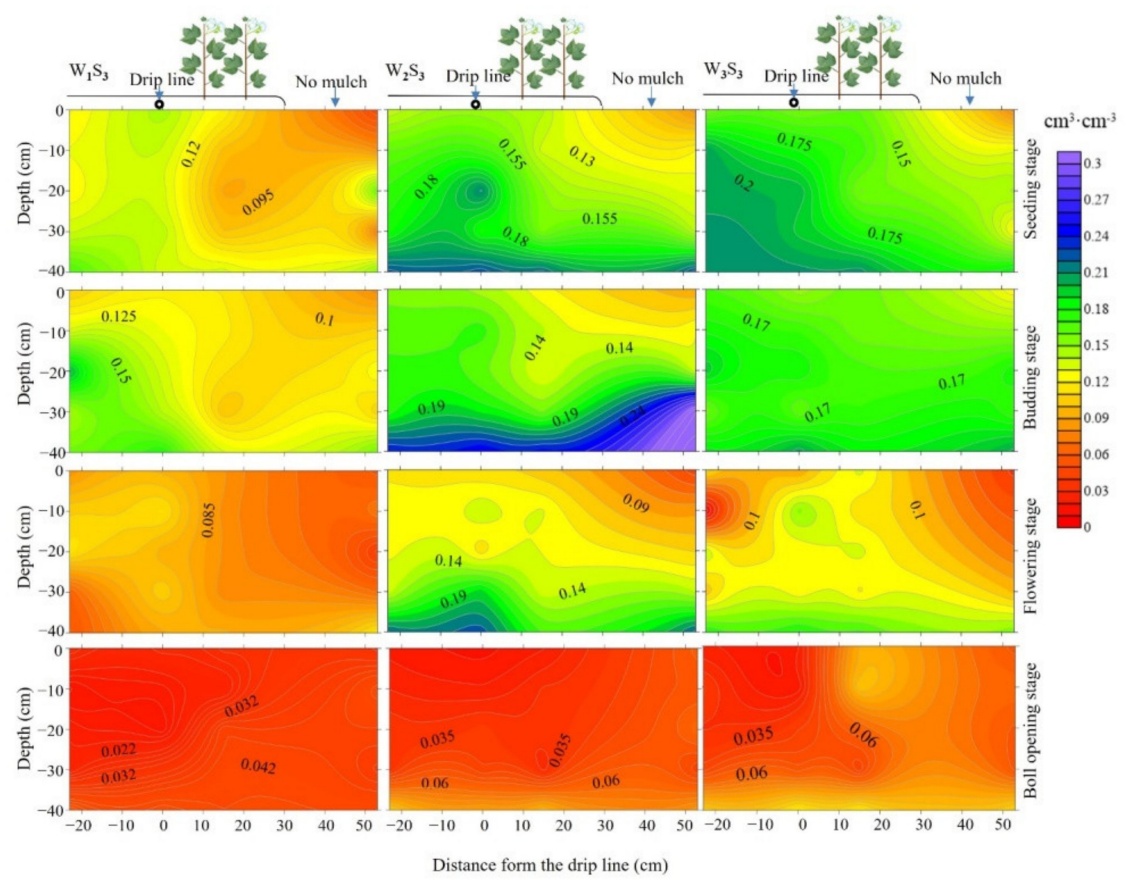

(c)

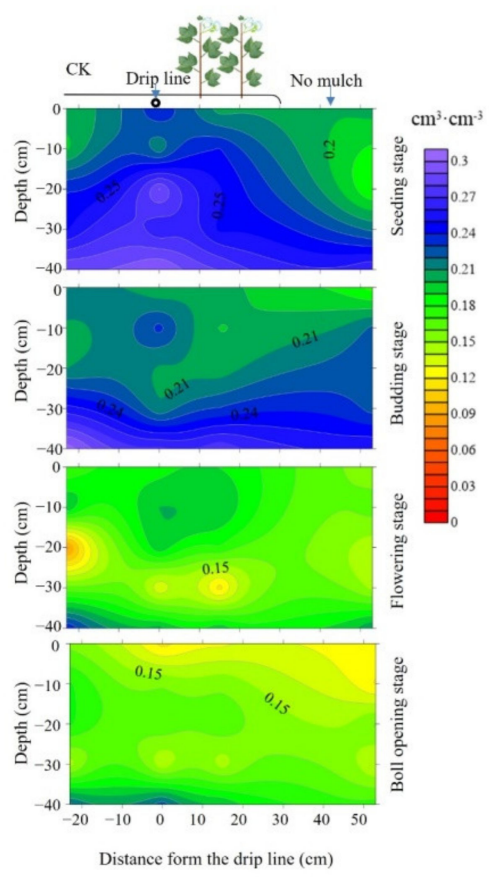

(d)

Figure 3. Dynamic changes in soil moisture content in 0-40 cm soil layer of each treatment. (a) irrigation application at the seeding stage; (b) irrigation application at the seeding stage + budding stage; (c) irrigation application at the seeding stage + budding stage + flowing stage; (d) no irrigation application (CK).

3.2. Effects of Brackish Water Irrigation Amounts and Applications on Dynamic Changes in Soil Salinity

Figure 4 shows the distributions of TDS in the $0-40 \mathrm{~cm}$ soil layer of each treatment. At the seedling stage, most of the $0-40 \mathrm{~cm}$ salt was leached to the deeper soil. According to the different irrigation levels, the desalination zone continued to move beyond the film- 
mulched zones, and the TDS of $\mathrm{W}_{1}$ was significantly lower than $\mathrm{W}_{2}$ and $\mathrm{W}_{3}$ treatments (Figure 4a).

At the budding stage in the vertical direction, the TDS accumulation depth of $S_{2}$ and $S_{3}$ increased with the increase in the irrigation amount (Figure $4 b, c)$. The TDS of $S_{1}$ treatment in the $0-40 \mathrm{~cm}$ soil increased continuously (Figure $4 \mathrm{a}$ ). In the horizontal direction, the TDS of narrow raw and non-mulched areas of $S_{1}$ treatments increased. The TDS of non-mulched areas of $S_{3}$ was still high, and it may be unfavorable for the low single irrigation amount (Figure 4c). The TDS of CK treatment in narrow raw areas increased rapidly due to the cotton's water absorption (Figure 4d).

At the flowering stage, SWC was further reduced, and salt was moved upward together with deeper soil moisture. In the vertical direction, $\mathrm{S}_{1}$ treatments kept low TDS in film-mulched zones (Figure 4a). The salt accumulation of $S_{2}$ occurred in the $30-40 \mathrm{~cm}$ soil layer (Figure $4 \mathrm{~b}$ ). Salt accumulation of $S_{1}$ occurred in the $20 \mathrm{~cm}$ soil layer (Figure $4 \mathrm{a}$ ). The TDS of CK treatment in film-mulched zones increased the most, reaching $5.5 \mathrm{~g} \mathrm{~kg}^{-1}$, which did not adapt to the reproductive growth of cotton. Generally, in the horizontal direction, the TDS in film-mulched zones was lower than that of the non-mulched area.

At the boll-opening stage, TDS in the topsoil of each treatment showed a similar pattern, where the TDS in film-mulched zones was lower than that in the $0-20 \mathrm{~cm}$ soil layer of the non-mulched area. In the $20-40 \mathrm{~cm}$ soil layer, compared to the flowering stage, the TDS of $\mathrm{W}_{3} \mathrm{~S}_{1}$ increased more with the drip line and the TDS of $\mathrm{W}_{2} \mathrm{~S}_{1}$ increased in the narrow row, resulting in the TDS in the film-mulched zones being higher than that in the non-mulched area (Figure 4a). The TDS of $S_{2}$ and $S_{3}$ increased in non-mulched areas and decreased in film-mulched zones (Figure $4 b, c$ ). Comparing $S_{2}$ with $S_{3}$, the TDS of $S_{2}$ in non-mulched areas was higher than that of $S_{3}$. Due to the difference in the total irrigation amount, the desalination effect of high volume irrigation treatments $\left(\mathrm{W}_{3}\right)$ was better than that of medium volume irrigation treatments $\left(\mathrm{W}_{2}\right)$ and low volume irrigation treatments $\left(\mathrm{W}_{1}\right)$. For $\mathrm{CK}$ treatment, a lack of irrigation application resulted in salt accumulation in the 0-20 cm soil layer, high TDS reduced the soil water's availability and soil evaporation led to higher surface salinity.

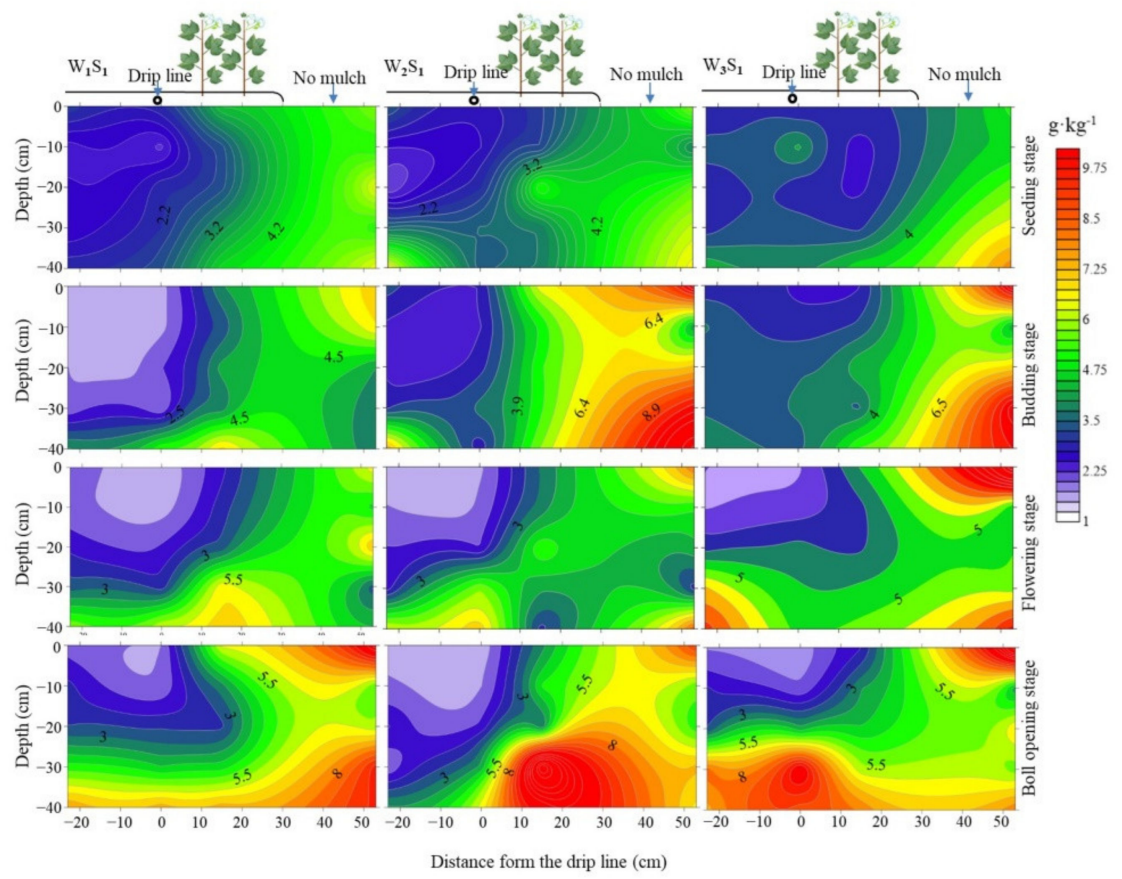

(a)

Figure 4. Cont. 


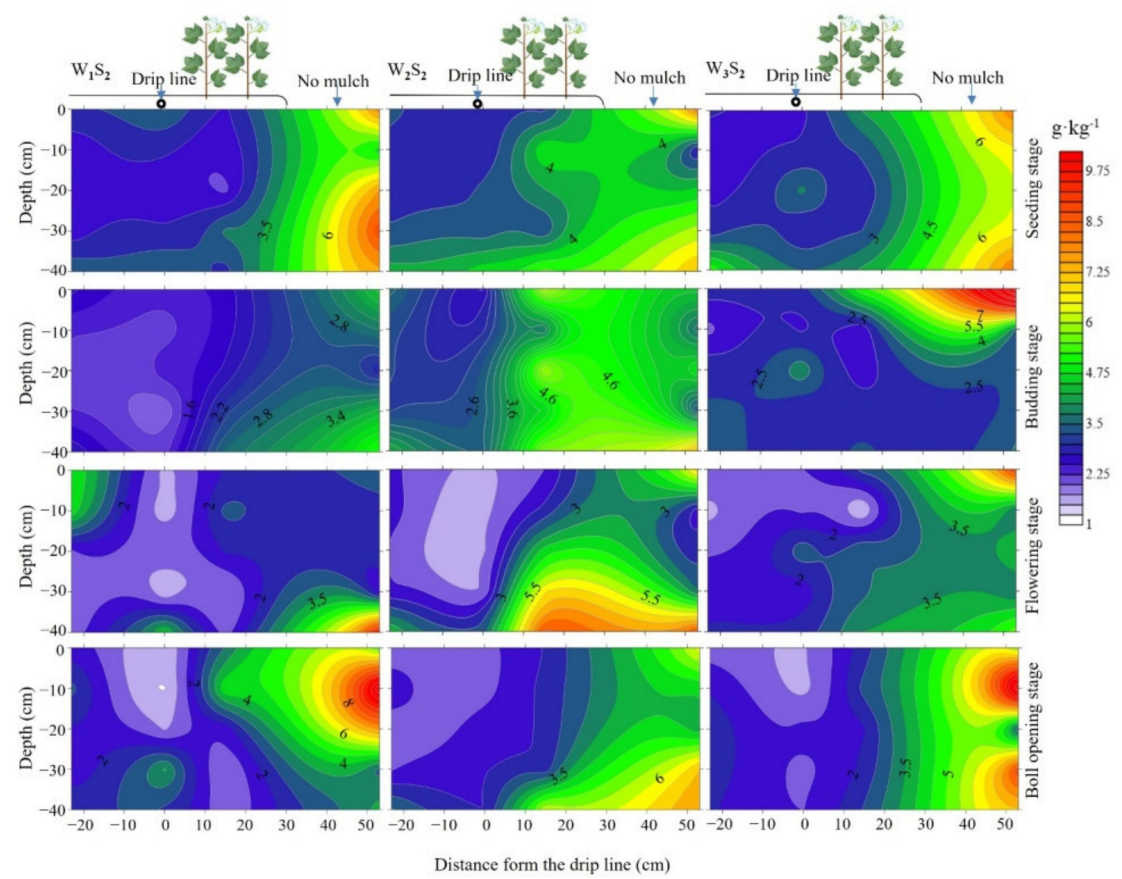

(b)

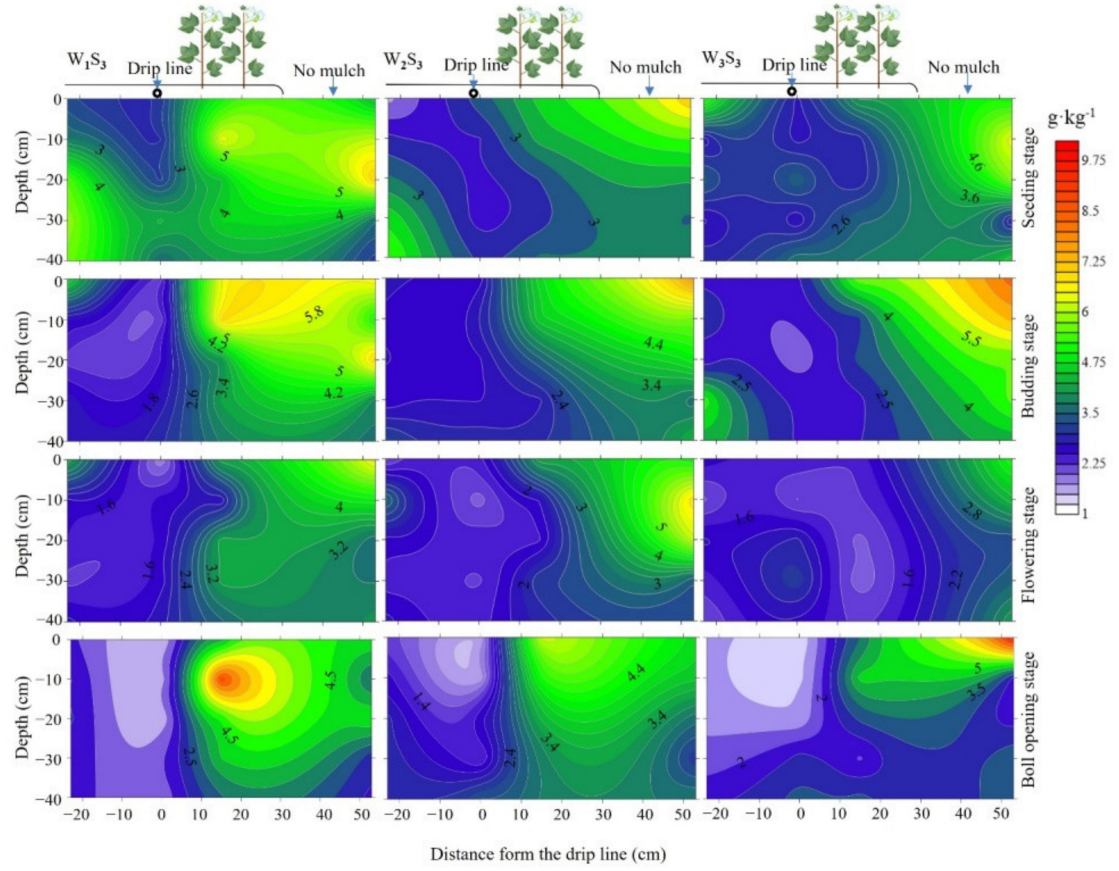

(c)

Figure 4. Cont. 


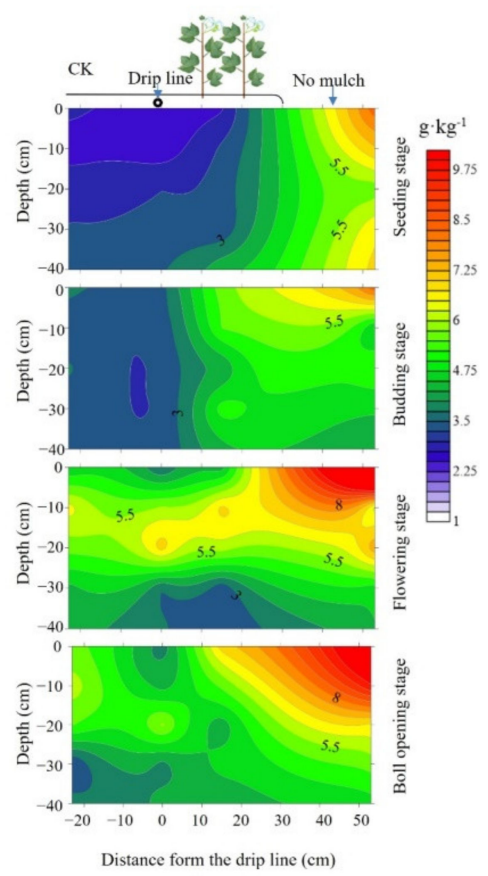

(d)

Figure 4. Dynamic changes of soil salinity content in 0-40 cm soil layer of each treatment. (a) irrigation application at the seeding stage; (b) irrigation application at the seeding stage + budding stage; (c) irrigation application at the seeding stage + budding stage + flowing stage; (d) no irrigation application (CK).

Figure 5 shows salt accumulation in the $0-100 \mathrm{~cm}$ soil profile at harvest stage. $\mathrm{W}_{3} \mathrm{~S}_{3}$ treatment had the lowest salt accumulation and $\mathrm{W}_{3} \mathrm{~S}_{1}$ treatment had the highest salt accumulation. Compared with $\mathrm{W}_{3} \mathrm{~S}_{1}$ and $\mathrm{W}_{3} \mathrm{~S}_{2}, \mathrm{~W}_{3} \mathrm{~S}_{3}$ treatment had a $39.5 \%$ and $2.8 \%$ reduction in salt accumulation, respectively. In addition, with the increase in the irrigation amount, the soil salt accumulation in $S_{2}$ and $S_{3}$ treatments decreased continuously, while in $S_{1}$ treatment it first decreased and then increased. Under the same irrigation level $\left(W_{1}, W_{2}\right.$, $W_{3}$ ), the salt accumulation in $S_{1}$ was significantly higher than in $S_{2}$ and $S_{3}$. With an increase in irrigation level, the difference of accumulation between different irrigation applications increased. For $S_{1}$ treatment, the soil salt accumulation of the whole profile increased, and the increase was more significant in the $0-40 \mathrm{~cm}$ soil profile. Compared with $\mathrm{W}_{2} \mathrm{~S}_{1}$ and $\mathrm{W}_{1} \mathrm{~S}_{1}$, the TDS of $\mathrm{W}_{3} \mathrm{~S}_{1}$ increased by $14.6 \%$ and $31.3 \%$, respectively. For $\mathrm{S}_{2}$ treatment, the soil salt accumulation above $40 \mathrm{~cm}$ decreased with the increase in irrigation level $\left(\mathrm{W}_{1}, \mathrm{~W}_{2}\right.$, $\mathrm{W}_{3}$ ), while the soil salt accumulation below $40 \mathrm{~cm}$ increased with the increase in irrigation level, indicating that the increase in irrigation level could move the salt deeper into the soil. For $\mathrm{W}_{2} \mathrm{~S}_{3}$ and $\mathrm{W}_{2} \mathrm{~S}_{3}$ treatment, the soil salt accumulation above $60 \mathrm{~cm}$ showed a decreasing trend, while the soil salt accumulation below $60 \mathrm{~cm}$ showed an increasing trend, and the depth of the desalination zone increased compared with $S_{2}$ treatment $\left(W_{1}, W_{2}, W_{3}\right)$. For CK treatment, the soil salt accumulation above $40 \mathrm{~cm}$ was the lowest compared with other treatments, but above $40 \mathrm{~cm}$ it was the largest. Compared with $\mathrm{W}_{3} \mathrm{~S}_{1}, \mathrm{~W}_{3} \mathrm{~S}_{2}$ and $\mathrm{W}_{3} \mathrm{~S}_{3}$, the salt accumulation at $0-40 \mathrm{~cm}$ increased by $14.28 \%, 47.68 \%$ and $54.40 \%$, respectively. The results showed that with the increase in the number of irrigation applications and the irrigation amount, the surface salt would move down to the deeper soil. They also showed that the single irrigation amount should not be too large, which would easily lead to surface salt accumulation and produce a physiological drought for cotton. 


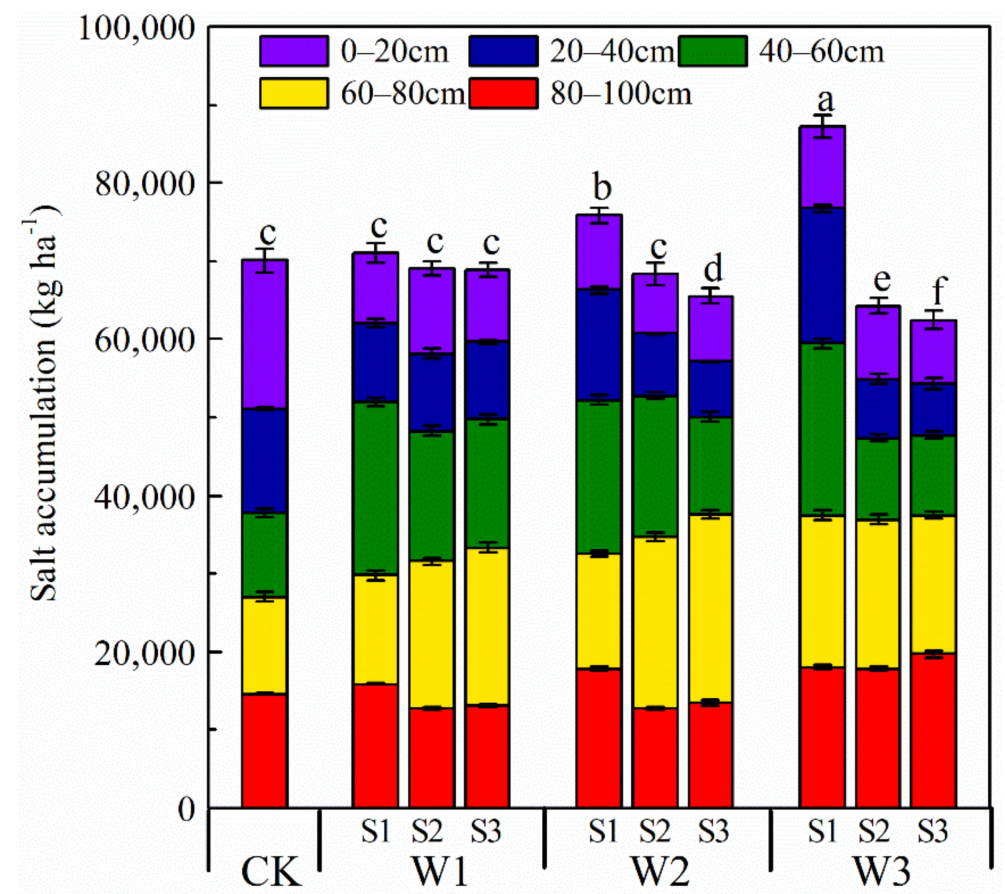

Figure 5. Salt accumulation in $0-100 \mathrm{~cm}$ soil profile at harvest stage.

\subsection{Effects of Brackish Water Irrigation Amounts and Applications on Cotton Growth, WUE} and Yield

Under the same irrigation levels, the plant height was significantly different between the $W_{1}, W_{2}$ and $W_{3}$ treatments. With the $S_{1}$ irrigation applications, the plant height decreased when the amount of irrigation increased. For the $S_{2}$ and $S_{3}$ irrigation applications, the plant height increased as the amount of irrigation increased. Compared with the low irrigation amount $\left(\mathrm{W}_{1}\right)$, the middle irrigation amount $\left(\mathrm{W}_{2}\right)$ and the high irrigation amount $\left(W_{3}\right)$ increased plant height by $41.2-64.5 \%$ under $S_{2}$. Meanwhile, $W_{2} S_{3}$ and $W_{3} S_{3}$ increased plant height by $23.9-30.3 \%$ compared with $\mathrm{W}_{1} \mathrm{~S}_{3}$ (Figure 6a).

The stem diameter increased with irrigation applications and irrigation amount; the largest stem diameter was observed in $\mathrm{CK}$ and $\mathrm{W}_{3} \mathrm{~S}_{3}$ treatments. Compared with a low irrigation amount $\left(W_{1}\right)$, the medium irrigation amount $\left(W_{2}\right)$ and the high irrigation amount $\left(\mathrm{W}_{3}\right)$ of $\mathrm{S}_{2}$ irrigation application increased stem diameter by 8.4-24.4\%. Meanwhile, $\mathrm{W}_{2} \mathrm{~S}_{3}$ and $\mathrm{W}_{3} \mathrm{~S}_{3}$ increased stem diameter by $2.6-22.7 \%$ compared with $\mathrm{W}_{1} \mathrm{~S}_{3}$ (Figure $6 \mathrm{~b}$ ).

The LAI increased with the increase in irrigation amount; however, irrigation applications had no significant effect on LAI under medium and low irrigation amounts. Compared with $W_{1}$, the LAI of the $W_{2}$ and $W_{3}$ treatments was increased by $7.05-40.64 \%$ and $24.17-86.20 \%$, respectively (Figure 6c). The largest LAI was observed in $\mathrm{W}_{3} \mathrm{~S}_{2}$ treatment.

With the increase in irrigation amount, the aboveground dry matter mass of $S_{2}$ treatment and $S_{3}$ treatment increased significantly (Figure 6d). However, when irrigation applications were only applied at the seedling stage, the relationship between the accumulation of dry matter in the shoot and water quantity was not significant in $S_{1}$ treatment, which indicated that too few irrigation applications would hinder and reduce dry matter accumulation.

Under the same irrigation level, the yield increased with the increase in irrigation applications. The yield of $S_{2}$ and $S_{3}$ treatments increased significantly with the increase in irrigation amount (Figure 6e). The yield of $S_{1}$ treatment was not significantly increased with the increase in irrigation amount. A maximum yield of $5685 \mathrm{~kg} \mathrm{ha}^{-1}$ was observed in $\mathrm{W}_{3} \mathrm{~S}_{3}$ treatment. Compared with $\mathrm{W}_{3} \mathrm{~S}_{1}, \mathrm{~W}_{3} \mathrm{~S}_{2}$ and $\mathrm{CK}$, the yield was increased by $39.59 \%$, $7.85 \%$ and $11.25 \%$, respectively.

The WUE of $S_{3}$ treatments was significantly higher than that of other treatments under the same irrigation amount of $W_{2}$ and $W_{3}$, respectively. However, at the irrigation amount 
level of $W_{1}$, there was no significant difference between $S_{2}$ and $S_{3}$ treatments (Figure $6 \mathrm{f}$ ). WUE decreased with the increase in irrigation amount, and the WUE of $W_{1} S_{2}, W_{1} S_{3}, W_{2} S_{3}$ and $W_{3} S_{3}$ showed no significant difference. The minimum WUE was observed in $W_{3} S_{1}$ treatment as $0.64 \mathrm{~kg} \mathrm{~m}^{-3}$, which indicated that multiple irrigation applications during different growth stages could increase cotton yield and WUE.
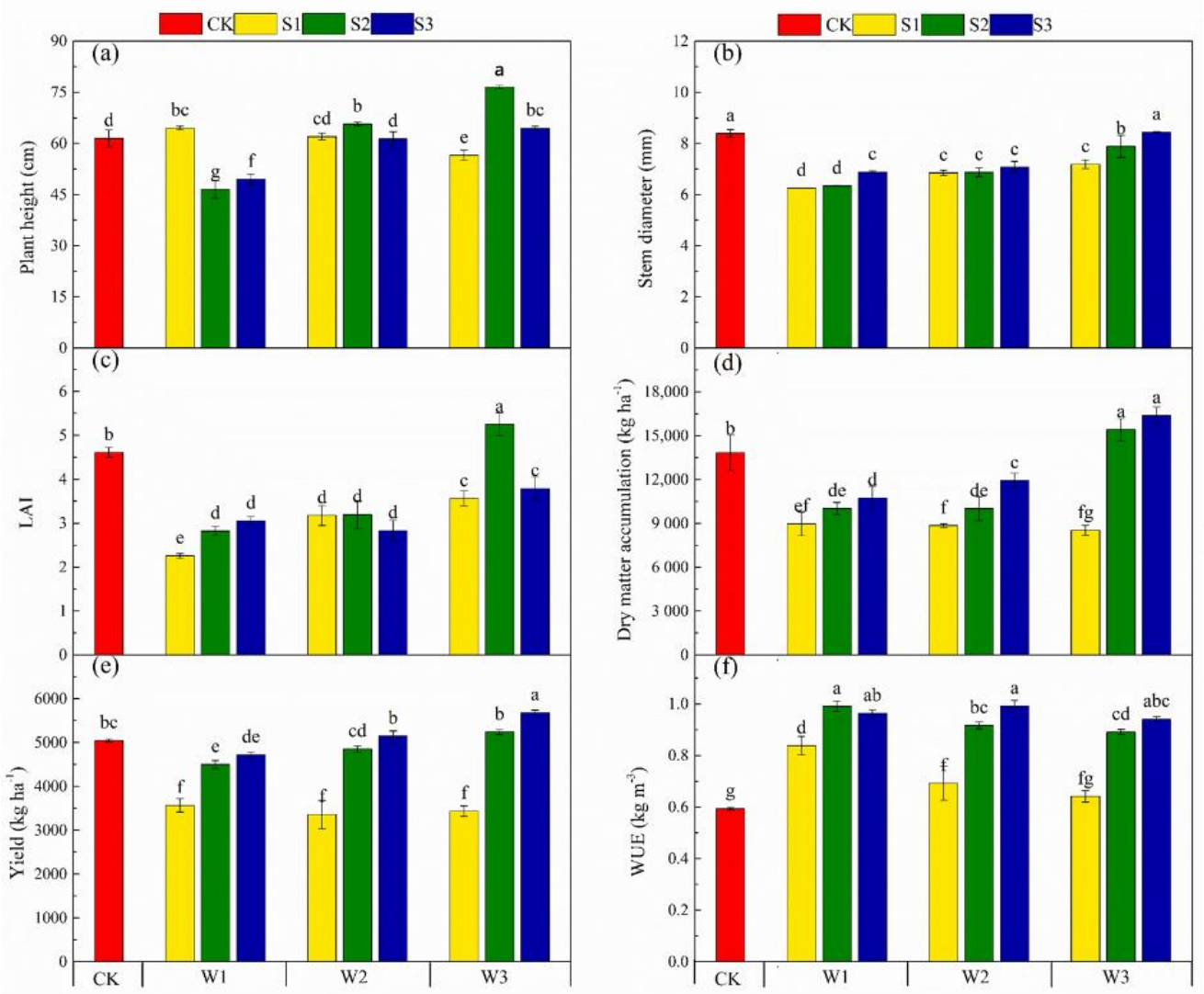

Figure 6. Cotton growth, yield and WUE under different treatments. (a) plant height; (b) stem diameter; (c) LAI; (d) dry matter accumulation; (e) yield; (f) WUE.

\section{Discussion}

Mulched drip irrigation is an effective measure to regulate soil water and salt when brackish water resources are used [16], because salt brought into the soil by brackish water irrigation causes a decrease in soil water's potential, leading to plant salt stress on crops. A higher SWC is therefore required during the cotton's growth stages. While we found that using brackish water for leaching during the growth stage can regulate the SWC in film-mulched zones, maintaining a high level of soil moisture in the cotton water demand critical stage (budding stage and flowering stage), it can also control the salt content below the root zones and reduce the TDS during the cotton growing season. This also conformed to the research results proposed by Li and Kang [27], who found that drip irrigation with brackish water effectively improved saline-sodic soils. In this study, it was found that irrigation applications directly affected the SWC of cotton fields under the same irrigation levels. Since the SWC gradually decreased with the growing of cotton, the increase in irrigation applications can be used for supplementary irrigation at later growth stages, such as the budding stage and flowering stage, to store water in the soil and meet the water requirement for cotton. The SWC in the membrane of $S_{1}$ and $S_{2}$ treatments decreased at the flowering stage, but the water consumption of cotton reached the maximum at the flowering and boll stages [28]. At this time, the decrease in SWC is not conducive to the reproductive growth of cotton, which indicates that if no irrigation application is carried out in the late growth stages, soil salinity may move with water and accumulation. In 
addition, the accumulated salt in the root layer would cause serious water and salt stress on cotton, leading to premature senescence and yield reduction. However, excessive irrigation amounts also increased SWC in non-mulched zones, leading to high soil evaporation.

As drip irrigation under film can only moisten part of the soil profile, salt will inevitably accumulate in shallow moist soil [29], and the depth of salt accumulation is closely related to the irrigation amounts. In our study, we found leaching with brackish water during the cotton's growing season can reduce the TDS in the root zones and total salt accumulation in the entire soil layer. For $S_{1}$ treatment, soil salts did not accumulate in the root zones at the budding stage, suggesting that a higher irrigation rate was beneficial in retaining soil salt at the deeper soil layers [18]. With the growth of cotton, salt accumulates in the surface and film of bare soil at 30-40 cm during the flowering and boll opening stages. For $S_{2}$ treatment, salt accumulation was only observed at the flowering stage and only along the narrow line of the $W_{2}$ irrigation level. $S_{3}$ kept the soil at a low salt level throughout the growth stage, apart from the low irrigation level $\left(\mathrm{W}_{1}\right)$ at the budding and ball opening stages in the narrow row. The reason may be that the low irrigation amount during the growth stages cannot satisfy the water absorption needs of the root system, which consumes the water stored in the soil instead. Due to cotton transpiration and soil evaporation, the accumulated salt can still return to the root zone. When irrigation is applied at this time, the salt that was about to migrate upward would migrate downward again with the dripping water, which also explains why a reasonable irrigation application was conducive to preventing the accumulation of salt in the soil surface. The TDS in the non-mulched zones of each treatment varied greatly, because the plastic film mulching had a significant capacity for soil moisture conservation and salt suppression. Soils in non-mulched zones continued to evaporate, and the salt content gradually accumulated. The irrigation amount in the seeding stage was large in $S_{1}$, and the increase of SWC in film-mulched zones also increased the ineffective evaporation of soil. As a result, the salt accumulation in film-mulched zones increased. With the increase in irrigation applications, the smaller the single irrigation amount was, the more difficult it was for the wetting front to reach the non-mulched zones. As a result, the water content, ineffective evaporation and salt accumulation decreased in non-mulched zones. Previous studies have shown that higher salt content of irrigation water and a lower irrigation amount will lead to an increase in soil salt accumulation [30]. Our study showed that the soil salt accumulation in $S_{2}$ and $S_{3}$ treatments decreased with the increase in irrigation amount, but the soil salt accumulation in $S_{1}$ treatment showed an increasing trend. The possible reason for this was that the plant LAI in the seeding stage could not completely cover the non-mulched zones, and irrigation application at this time caused a sever soil evaporation and had a risk of secondary salinization. In addition, the duration of saline-alkali stress on cotton depends on the irrigation applications, and after irrigation, the crop may still be under salt stress in the later growth period, so it is necessary to control the soil salinity in the growing season [31]. The study of Zhang [22] et al. showed that the optimal irrigation application was at about 41 days after sowing, which could reduce the duration of high salinity stress. Part of the results of this study was similar to that. For $S_{1}$ treatment, there was only one irrigation application, and the average TDS in the late growth period reached $4.80-6.22 \mathrm{~g} \mathrm{~kg}^{-1}$. During the late growth period, the cotton is always under high salinity stress, which is not conducive to the growth of cotton. In $S_{3}$ treatment, the water was divided into three stages and washed several times. This brackish water utilization strategy reduced the soil salt content in the later growth stage. The TDS of $\mathrm{S}_{3}$ treatment was $4.10-4.17 \mathrm{~g} \mathrm{~kg}^{-1}$, and soil TDS in the mulched zones was $3.59-3.70 \mathrm{~g} \mathrm{~kg}^{-1}$. Too much salt destroyed the nutritional balance in the plant body, led to a disorder of cell metabolism and causing a series of problems, such as the decrease of yield.

After irrigation with brackish water, the cotton growth depended on the TDS in the root zones [32]. In addition, film-mulched drip irrigation can improve soil water and salt conditions by controlling the irrigation amount and time, promoting dry matter accumulation of cotton and increasing yield $[13,33]$. In our study, the increase of irrigation water 
volume promoted the dry matter transport, accumulation and yield of cotton. However, the yield of $S_{1}$ treatment did not increase with the increase in irrigation amount. The reason may be because SWC decreased gradually with the growth of cotton, and the amount of TDS increased in the later growth stages after irrigation was applied at the seeding stage. Excessive salt content in root zones impeded the growth and development of the cotton's root system, decreased root activity and inhibited the physiological function of the root $[10,34]$. Meanwhile, multiple irrigation applications $\left(S_{2} S_{3}\right)$ during the growth stage can not only replenish water, but also help to reduce soil surface salt, and are more conducive to dry matter accumulation. However, Wang et al. [35] reported that excessive drip irrigation resulted in excess vegetative growth at the later stage of growth, causing the decrease in the boll opening rate and seed cotton yield. This phenomenon was not found in our study, and the possible reason was that the last irrigation application time of $S_{3}$ was earlier, which avoided the vigorous growth of vegetative organs such as stems and leaves and inhibited the reproductive growth of cotton, resulting in low cotton batching rate and affecting the yield and reducing the quality. Cotton plant height increases slowly after the budding stage [36]; however, LAI reaches the maximum height at the flowering stage and then decreased gradually, while dry matter, yield and stem diameter increased within days [37]. The greater irrigation amount of $S_{2}$ at the budding stage increased soil moisture and reduced the salt content in the root zones. Suitable soil moisture and salt content conditions were very conducive to the growth of cotton, which was the possible reason for the high plant height and LAI of $S_{2}$. At the flowering stage, cotton is more sensitive to drought [38]. Because of the gradual depletion of soil moisture and the increase in salt content in the zone area, the cotton's roots had difficulty absorbing water. The higher LAI of $S_{2}$ further aggravated the physiological drought of plants, which was not conducive to the accumulation of dry matter mass, resulting in the average decrease of biomass by $6.3-19.3 \%$ and yield by $4.94-8.52 \%$ compared with that in the $S_{3}$ treatment, respectively. Previous studies have shown that increasing the irrigation amount is not conducive to improving water use efficiency $[13,39]$. In this study, it was found that with the increase in irrigation amount, the WUE of $S_{1}$ and $S_{2}$ treatment did not decrease significantly, while the WUE of $S_{3}$ treatment first increased and then decreased with the increase in irrigation amount. It may be that in areas with relatively high soil salinization, decreasing the irrigation amount reduces drainage loss, but higher root salt content reduces soil water availability. Moreover, higher soil salinity reduces the membrane channel activity, water channel activity, stomatal conductance, conduction and ion balance of cotton [40]. On the other hand, the lower soil moisture in the boll opening stage also avoided the delay of cotton maturation due to excessive irrigation, which reduced the number of bolls and lint cotton yield [35]. In addition, compared with treatment $\mathrm{W}_{2}$ and treatment $\mathrm{W}_{1}$, the average SWC at the flowering stage of $\mathrm{W}_{3}$ increased by $9.65 \%$ and $26.98 \%$, respectively, but the yield did not increase. In this study, we found that when the soil TDS was lower than $4.8 \mathrm{~g} \mathrm{~kg}^{-1}$, the increase in soil moisture was helpful to increase the biomass and yield of cotton, while a TDS higher than $4.8 \mathrm{~g} \mathrm{~kg}^{-1}$ would significantly reduce the availability of soil moisture, which was not conducive to the increase in yield.

The amount and irrigation application of brackish water during the growth stages on soil environment and cotton growth was explored. Compared with the one-time brackish water flooding irrigation mode adopted in local spring irrigation, brackish water irrigation divided into three applications in the growth stages had less negative effect on soil environment and cotton growth. However, the effects of different salinities and alternate modes of brackish and freshwater application on farmland soil, water environment and cotton growth still need further experimental research. For other regions, whether brackish water irrigation applied during the growth period can be used must be dependent on local conditions, and the salinity of irrigation water and the salinization degree of soil should be fully considered before implementation. 


\title{
5. Conclusions
}

The usage of brackish water for irrigation in saline lands is challenging and requires more rational use to improve agricultural sustainability. Our study studied water and salt dynamics, dry matter accumulation, yield and water use efficiency of cotton with different brackish water irrigation levels and application treatments. The results show that reasonable irrigation application and brackish water irrigation levels increased SWC in root zones at the flowering stage, reduced soil TDS in mulched zones and created a good water and salt environment for cotton growth. In addition, compared with CK treatment adopted by local farmers, reasonable irrigation application and brackish water irrigation levels did not reduce the yield and biomass, but did improve water use efficiency, avoiding the accumulation of soil salt and improving the soil's sustainability. Considering high yield, water conservation and salt leaching, an irrigation amount of $240 \mathrm{~mm}$ of brackish water at three growth stages with $80 \% \mathrm{ET}_{\mathrm{c}}$ for irrigation is recommended for the sustainable production of cotton in southern Xinjiang. However, we also need to pay attention to irrigation application to avoid delaying maturity and reducing the number of open bolls.

\begin{abstract}
Author Contributions: Conceptualization, J.F.; methodology, F.Z.; software, Y.L. (Yuepeng Li); writing-original draft preparation, C.X.; writing-review and editing, M.L., J.F. and F.Z.; supervision, Y.L. (Yi Li); funding acquisition, J.F.; investigation, H.C. and X.H.; visualization, J.C. All authors have read and agreed to the published version of the manuscript.

Funding: This research was jointly supported by National Natural Science Foundation of China (No. 52079114, 51979231), the High-end Foreign Experts Introduction Project (G20200027071), the Chinese Universities Scientific Fund (2452020018) and the "111" Project (No. B12007).
\end{abstract}

Institutional Review Board Statement: Not applicable.

Informed Consent Statement: Not applicable.

Data Availability Statement: All data will be made available on request to the correspondent author's email with appropriate justification.

Acknowledgments: Huijuan Wang at the Department of Foreign Languages, Northwest A\&F University helped editing and polishing of the manuscript.

Conflicts of Interest: The authors declare no conflict of interest.

\section{References}

1. Li, M.; Xiao, J.; Bai, Y.; Du, Y.; Zhang, F.; Cheng, H.; Wang, H. Response mechanism of cotton growth to water and nutrients under drip irrigation with plastic mulch in Southern Xinjiang. J. Sens. 2020, 2020, 1-16. [CrossRef]

2. Chen, W.; Hou, Z.; Wu, L.; Liang, Y.; Wei, C. Evaluating salinity distribution in soil irrigated with saline water in arid regions of northwest China. Agric. Water Manag. 2010, 97, 2001-2008. [CrossRef]

3. Kang, S.; Hao, X.; Du, T.; Tong, L.; Su, X.; Lu, H.; Li, X.; Huo, Z.; Li, S.; Ding, R. Improving agricultural water productivity to ensure food security in China under changing environment: From research to practice. Agric. Water Manag. 2017, $179,5-17$. [CrossRef]

4. Yang, P.; Hu, H.; Tian, F.; Zhang, Z.; Dai, C. Crop coefficient for cotton under plastic mulch and drip irrigation based on eddy covariance observation in an arid area of northwestern China. Agric. Water Manag. 2016, 171, 21-30. [CrossRef]

5. Ning, S.; Shi, J.; Zuo, Q.; Wang, S.; Ben-Gal, A. Generalization of the root length density distribution of cotton under film mulched drip irrigation. Field Crop. Res. 2015, 177, 125-136. [CrossRef]

6. Wang, Z.; Fan, B.; Guo, L. Soil salinization after long-term mulched drip irrigation poses a potential risk to agricultural sustainability. Eur. J. Soil Sci. 2018, 70, 20-24. [CrossRef]

7. Yan, F.; Zhang, F.; Fan, X.; Fan, J.; Wang, Y.; Zou, H.; Wang, H.; Li, G. Determining irrigation amount and fertilization rate to simultaneously optimize grain yield, grain nitrogen accumulation and economic benefit of drip-fertigated spring maize in northwest China. Agric. Water Manag. 2020, 243, 106440. [CrossRef]

8. Wang, Z.; Jin, M.; Šimůnek, J.; van Genuchten, M. Evaluation of mulched drip irrigation for cotton in arid Northwest China. Irrig. Sci. 2013, 32, 15-27. [CrossRef]

9. Shahrokhnia, H.; Wu, L. SALEACH: A new web-based soil salinity leaching model for improved irrigation management. Agric. Water Manag. 2021, 252, 106905. [CrossRef]

10. Chen, W.; Jin, M.; Ferre, P.; Liu, Y.; Xian, Y.; Shan, T.; Ping, X. Spatial distribution of soil moisture, soil salinity, and root density beneath a cotton field under mulched drip irrigation with brackish and fresh water. Field Crop. Res. 2018, 215, 207-221. [CrossRef] 
11. Rahman, M.; Hagare, D.; Maheshwari, B.; Dillon, P. Impacts of prolonged drought on salt accumulation in the root zone due to recycled water irrigation. Water Air Soil Pollut. 2015, 226, 1-18. [CrossRef]

12. Rozema, J.; Flowers, T. ECOLOGY: Crops for a Salinized World. Science 2008, 322, 1478-1480. [CrossRef] [PubMed]

13. Ren, F.; Yang, G.; Li, W.; He, X.; Gao, Y.; Tian, L.; Li, F.; Wang, Z.; Liu, S. Yield-compatible salinity level for growing cotton (Gossypium hirsutum L.) under mulched drip irrigation using saline water. Agric. Water Manag. 2021, 250, 106859. [CrossRef]

14. Min, W.; Guo, H.; Zhou, G.; Zhang, W.; Ma, L.; Ye, J.; Hou, Z. Root distribution and growth of cotton as affected by drip irrigation with saline water. Field Crop. Res. 2014, 169, 1-10. [CrossRef]

15. Hu, H.; Tian, F.; Hu, H. Soil particle size distribution and its relationship with soil water and salt under mulched drip irrigation in Xinjiang of China. Sci. China E Technol. Sci. 2011, 54, 1568-1574. [CrossRef]

16. Li, X.; Jin, M.; Zhou, N.; Huang, J.; Jiang, S.; Telesphore, H. Evaluation of evapotranspiration and deep percolation under mulched drip irrigation in an oasis of Tarim basin, China. J. Hydrol. 2016, 538, 677-688. [CrossRef]

17. Kang, Y.; Wang, R.; Wan, S.; Hu, W.; Jiang, S.; Liu, S. Effects of different water levels on cotton growth and water use through drip irrigation in an arid region with saline ground water of Northwest China. Agric. Water Manag. 2012, 109, 117-126. [CrossRef]

18. Liu, M.; Yang, J.; Li, X.; Liu, G.; Yu, M.; Wang, J. Distribution and dynamics of soil water and salt under different drip irrigation regimes in northwest China. Irrig. Sci. 2012, 31, 675-688. [CrossRef]

19. Xue, J.; Ren, L. Conjunctive use of saline and non-saline water in an irrigation district of the Yellow River Basin. Irrig. Drain. 2017, 66, 147-162. [CrossRef]

20. Hassanli, M.; Ebrahimian, H. Cyclic use of saline and non-saline water to increase water use efficiency and soil sustainability on drip irrigated maize in a semi-arid region. Span. J. Agric. Res. 2016, 14, e1204. [CrossRef]

21. Li, N.; Kang, Y.; Li, X.; Wan, S. Response of tall fescue to the reclamation of severely saline coastal soil using treated effluent in Bohai Bay. Agric. Water Manag. 2019, 218, 203-210. [CrossRef]

22. Zhang, Y.; Li, X.; Šimůnek, J.; Shi, H.; Chen, N.; Hu, Q.; Tian, T. Evaluating soil salt dynamics in a field drip-irrigated with brackish water and leached with freshwater during different crop growth stages. Agric. Water Manag. 2020, 244, 106601. [CrossRef]

23. Allen, R.; Pereira, L.; Smith, M. Crop Evapotranspiration: Guidelines for Computing Crop Water Requirements; Food and Agriculture Organization of the United Nations: Rome, Italy, 1998; Volume 56.

24. Fan, J.; Yue, W.; Wu, L.; Zhang, F.; Cai, H.; Wang, X.; Lu, X.; Xiang, Y. Evaluation of SVM, ELM and four tree-based ensemble models for predicting daily reference evapotranspiration using limited meteorological data in different climates of China. Agric. For. Meteorol. 2018, 263, 225-241. [CrossRef]

25. Zou, H.; Fan, J.; Zhang, F.; Xiang, Y.; Wu, L.; Yan, S. Optimization of drip irrigation and fertilization regimes for high grain yield, crop water productivity and economic benefits of spring maize in Northwest China. Agric. Water Manag. 2019, $230,105986$. [CrossRef]

26. Cai, Y.; Wu, P.; Zhu, D.; Zhang, L.; Zhao, X.; Gao, X.; Ge, M.; Song, X.; Wu, Y.; Dai, Z. Subsurface irrigation with ceramic emitters: An effective method to improve apple yield and irrigation water use efficiency in the semiarid Loess Plateau. Agric. Ecosyst. Environ. 2021, 313, 107404. [CrossRef]

27. Li, X.; Kang, Y. Agricultural utilization and vegetation establishment on saline-sodic soils using a water-salt regulation method for scheduled drip irrigation. Agric. Water Manag. 2019, 231, 105995. [CrossRef]

28. Himanshu, S.K.; Fan, Y.; Ale, S.; Bordovsky, J. Simulated efficient growth-stage-based deficit irrigation strategies for maximizing cotton yield, crop water productivity and net returns. Agric. Water Manag. 2021, 250, 106840. [CrossRef]

29. Selim, T.; Berndtsson, R.; Persson, M.; Somaida, M.; El-Kiki, M.; Hamed, Y.; Mirdan, A.; Zhou, Q. Influence of geometric design of alternate partial root-zone subsurface drip irrigation (APRSDI) with brackish water on soil moisture and salinity distribution. Agric. Water Manag. 2012, 103, 182-190. [CrossRef]

30. Yuan, C.; Feng, S.; Huo, Z.; Ji, Q. Effects of deficit irrigation with saline water on soil water-salt distribution and water use efficiency of maize for seed production in arid Northwest China. Agric. Water Manag. 2018, 212, 424-432. [CrossRef]

31. Chauhan, S.K.; Chauhan, C.P.S.; Minhas, P.S. Effect of cyclic use and blending of alkali and good quality waters on soil properties, yield and quality of potato, sunflower and Sesbania. Irrig. Sci. 2007, 26, 81-89. [CrossRef]

32. Minhas, P.; Dubey, S.; Sharma, D. Comparative affects of blending, intera/inter-seasonal cyclic uses of alkali and good quality waters on soil properties and yields of paddy and wheat. Agric. Water Manag. 2007, 87, 83-90. [CrossRef]

33. Ning, S.; Zhou, B.; Shi, J.; Wang, Q. Soil water/salt balance and water productivity of typical irrigation schedules for cotton under film mulched drip irrigation in northern Xinjiang. Agric. Water Manag. 2020, 245, 106651. [CrossRef]

34. Liu, R.-X.; Zhou, Z.-G.; Guo, W.-Q.; Chen, B.-L.; Oosterhuis, D.M. Effects of N fertilization on root development and activity of water-stressed cotton (Gossypium hirsutum L.) plants. Agric. Water Manag. 2008, 95, 1261-1270. [CrossRef]

35. Wang, J.; Du, G.; Tian, J.; Zhang, Y.; Jiang, C.; Zhang, W. Effect of irrigation methods on root growth, root-shoot ratio and yield components of cotton by regulating the growth redundancy of root and shoot. Agric. Water Manag. 2020, 234, 106120. [CrossRef]

36. Li, M.; Du, Y.; Zhang, F.; Fan, J.; Ning, Y.; Cheng, H.; Xiao, C. Modification of CSM-CROPGRO-Cotton model for simulating cotton growth and yield under various deficit irrigation strategies. Comput. Electron. Agric. 2020, 179, 105843. [CrossRef]

37. Li, M.; Du, Y.; Zhang, F.; Bai, Y.; Fan, J.; Zhang, J.; Chen, S. Simulation of cotton growth and soil water content under film-mulched drip irrigation using modified CSM-CROPGRO-cotton model. Agric. Water Manag. 2019, 218, 124-138. [CrossRef]

38. Himanshu, S.K.; Ale, S.; Bordovsky, J.; Darapuneni, M. Evaluation of crop-growth-stage-based deficit irrigation strategies for cotton production in the Southern High Plains. Agric. Water Manag. 2019, 225, 105782. [CrossRef] 
39. Shareef, M.; Gui, D.; Zeng, F.; Waqas, M.; Zhang, B.; Iqbal, H. Water productivity, growth, and physiological assessment of deficit irrigated cotton on hyperarid desert-oases in northwest China. Agric. Water Manag. 2018, 206, 1-10. [CrossRef]

40. Rodriguez-Uribe, L.; Higbie, S.M.; Stewart, J.M.; Wilkins, T.; Lindemann, W.; Sengupta-Gopalan, C.; Zhang, J. Identification of salt responsive genes using comparative microarray analysis in Upland cotton (Gossypium hirsutum L.). Plant Sci. 2011, 180, 461-469. [CrossRef] [PubMed] 